\title{
The interactions between Quaternary Geology and Archaeology
}

\section{Wim Z. Hoek}

Department of Physical Geography, Faculty of Geosciences, Utrecht University, P.0. Box 80115, 3508 TC Utrecht, the Netherlands. Email:w.hoek@geo.uu.nl.

This special issue focuses on the interactions between Quaternary Geology and Archaeology and results from the INQUA-NL Symposium: 'Late Quaternary Climate Change: a Human Perspective' held on April $14^{\text {th }}$ 2009, KNAW Trippenhuis, Amsterdam. The symposium was attended by over 125 scientists and students with interest in the fields of Quaternary Geology and Archaeology. The symposium was organized for the INQUA Netherlands commission (INQUA-NL) by Wim Hoek, Faculty of Geosciences, Utrecht University (UU), Henry Hooghiemstra, Faculty of Science, University of Amsterdam (UvA), and Jos Deeben, National Service for Cultural Heritage (RCE). The INQUA Netherlands commission (INQUA-NL) is the Netherlands' national representation in INQUA, the International Union for Quaternary Research (see further www.geo.uu.nl/inqua-nl).

The Netherlands is a country made by humans, but before the large-scale impact of humans that formed the typical Dutch landscape, people inhabited our area and needed to be able to deal with natural disasters like climate change, river floods or sealevel change. In the field of archaeology, there is increasingly more space to include the environmental changes that partly determined the behaviour of prehistoric communities. The interactions between quaternary geology and archaeology are not only restricted to provide stratigraphical information during archaeological prospection or on exposures during excavations. Quaternary geology is increasingly applied to gain insight in the landscape development and environmental setting where people have lived in the past. Above this, predictive models can be improved by the interaction of archaeological and geological/palaeogeographical research (see also Deeben et al., 2010).

Furthermore, the increased cooperation results in exchange of knowledge and provides access to geologically interesting locations during archaeological excavations. This special issue of the Netherlands Journal of Geosciences gives some examples of recent studies where the interactions between Quaternary Geology and Archaeology are outlined.

In their contribution on Mid-Holocene water-level changes in the lower Rhine-Meuse delta Van de Plassche et al. (2010) give new information on the drowning of the Netherlands as a result of sea-level rise. This natural disaster is documented in the archeological record by the changes on particularly the riverdunes or 'donken' in the western Netherlands that acted as dry islands in a wet environment where prehistoric people were forced to adapt to water level rise. Included in this paper are new water-level index points collected during the Betuwelijn excavations from Hardinxveld-Giessendam: De Bruin and Polderweg, which enabled a unique view on the Mesolithic in the Netherlands (Louwe Kooijmans, 2001a, b).

Not only these river dunes, but also the higher natural levees in the delta are known for their early occupation (Berendsen \& Stouthamer, 2001). Van Dinter \& Van Zijverden (2010) show that not only these natural levees, but also the crevasse splay deposits that can reach far into the clayey flood basins, formed attractive places to live. Particularly these archaeological sites on crevasse splays contain valuable information because they are often sealed again by subsequent clay deposition resulting in, although more difficult to trace, beautifully preserved archaeological remains with a high information potential.

Palaeolithic artefacts are often dated by flint technology supported by their stratigraphical position. However, due to several geomorphological or biological processes, these artefacts may have been reworked or transported vertically and end up in a different stratigraphic position than originally deposited. In their contribution on the migration of Middle Palaeolithic artefacts Deeben et al. (2010) show that artefacts can be transported upward due to cryoturbation and upfreezing. Mixing with overlying younger material could be tested with the application of OSL dating techniques (Wallinga et al., 2007), showing that the process of periglacial transport indeed influences the stratigraphic position of artefacts. 
Unionid freshwater shells were used by Versteegh et al. (2010) to reconstruct changes in past river discharges from the River Rhine and Meuse. Most material of this study has been collected during archaeological excavations and the archaeological context was used for determining the age of the Unio shells. Medieval shells show decadal-scale variation in reconstructed $\delta^{18} 0_{\mathrm{w}}$ values, with a period of $~ 7-10$ years. These possibly reflect NAO variability, which is strongly linked to European spring-summer atmospheric circulations and related river runoff (Verdegaal et al., 2005).

Another example of an indirect link to archaeology is presented by Kluiving et al. (2010) who performed an inventory of possible pingo remnants in the Province of Friesland. Like in the Province of Drenthe (De Gans, 1982) numerous pingo remants are waiting to be discovered. Secondary objective of this study was to propose valuable pingo remnants for the provincial archaeological monument map, especially because they may contain a valuable record of environmental change during the period when Meso- and Early Neolithic hunter communities dwelled around in the northern Netherlands.

Finally, the human presence in the central Netherlands during early MIS 6 ( 170-190 Ka) is discussed by Van Balen and Busschers (2010). The stratigraphic position of early Middle Palaeolithic artefacts, in relation to what is known on the palaeogeography of the Netherlands (Busschers et al., 2008) places the artefacts in this cold stage. Although there is evidence that they have been transported, this transport was not over large distances as indicated by the fact that an important part of the artefacts have hardly been abraded. This paper is clear example of how Quaternary Geology can be applied in the evaluation of artefact age estimates.

\section{References}

Berendsen, H.J.A. \& Stouthamer, E., 2001. Palaeogeographic development of the Rhine-Meuse delta, the Netherlands. Koninklijke Van Gorcum, Assen: 288 pp.

Busschers, F. S., Kasse, C., Van Balen, R.T., Vandenberghe, J., Cohen, K., Weerts, H.J.T. \& Wallinga, J., 2007. Late Pleistocene evolution of the Rhine in the southern North Sea Basin: imprints of climate change, sea-leveloscillations and glacio-isostacy. Quaternary Science Reviews 26: 3216-3248.

Deeben, D., Hiddink, H., Huisman D.J., Müller, A., Schokker, J. \& Wallinga, J., 2010. Middle Palaeolithic artefact migration due to periglacial processes; a geological investigation into near-surface occurrence of Palaeolithic artefacts (Limburg-Eastern Brabant coversand region, the Netherlands). Netherlands Journal of Geosciences - Geologie en Mijnbouw 89(1): 35-50.

De Gans, W., 1982. Location, age and origin of pingo remnants in the Drentsche Aa Valley area (the Netherlands). Geologie en Mijnbouw 61: 147-158.

Kluiving S.J., Verbers, A.L.L.M. \& Thijs, W.J.F., 2010. Lithological analysis of 45 presumed pingo remnants in the northern Netherlands (Friesland): substrate control and fill sequences. Netherlands Journal of Geosciences - Geologie en Mijnbouw 89(1): 61-75.

Louwe Kooijmans, L.P. (ed.), 2001a. Hardinxveld-Giessendam Polderweg; een mesolithisch jachtkamp in het rivierengebied (5500-5000 v. Chr.). Rapportage Archeologische Monumentenzorg 83, Rijksdienst voor het Oudheidkundig Bodemonderzoek (Amersfoort): $488 \mathrm{pp}$.

Louwe Kooijmans, L.P. (ed.), 2001b. Hardinxveld-Giessendam De Bruin; een kampplaats uit het Laat-Mesolithicum en het begin van de Swifterbandcultuur. Rapportage Archeologische Monumentenzorg 88, Rijksdienst voor het Oudheidkundig Bodemonderzoek (Amersfoort): $550 \mathrm{pp}$.

Van Balen, R.T. \& Busschers, F.S., 2010. Human presence in the central Netherlands during early MIS 6 ( 170-190 Ka): evidence from early Middle Palaeolithic artefacts in ice-pushed Rhine-Meuse sediments. Netherlands Journal of Geosciences - Geologie en Mijnbouw 89(1): 77-83.

Van Dinter, M. \& Van Zijverden W.K., 2010. Settlement and land use on crevasse splay deposits; geoarchaeological research in the Rhine-Meuse Delta, the Netherlands. Netherlands Journal of Geosciences - Geologie en Mijnbouw 89(1): 21-34.
Van de Plassche, O. Makaske, B. Hoek, W.Z., Konert, M. \& Van der Plicht, J., 2010. Mid-Holocene water-level changes in the lower Rhine-Meuse delta (western Netherlands): implications for the reconstruction of relative mean sea-level rise, palaeoriver-gradients and coastal evolution. Netherlands Journal of Geosciences - Geologie en Mijnbouw 89(1): 3-20.

Verdegaal, S., Troelstra, S.R., Beets, C.K.J. \& Vonhof, H.B., 2005. Stable isotopic records in unionid shells as a paleoenvironmental tool. Netherlands Journal of Geosciences - Geologie en Mijnbouw 84(4): 403-408.

Versteegh, E.A.A., Vonhof, H.B., Troelstra, S.R. \& Kroon, D., 2010. A molluscan perspective on hydrological cycle dynamics in northwestern Europe. Netherlands Journal of Geosciences - Geologie en Mijnbouw 89(1): 51-60.

Wallinga, J., Davids, F. \& Dijkmans, J.W.A., 2007. Luminescence dating of Netherlands' sediments. Netherlands Journal of Geosciences - Geologie en Mijnbouw 86: 179-196. 